\title{
A comparison of probes for restriction fragment length polymorphism (RFLP) typing of Legionella pneumophila serogroup 1 strains
}

\author{
N. A. SAUNDERS, T. G. HARRISON, A. HATHTHOTUWA and A. G. TAYLOR
}

Molecular Biology Unit, Division of Microbiological Reagents and Quality Control, Central Public Laboratory, London NW9 $5 H T$

\begin{abstract}
Summary. The use of probes derived from rRNA sequences to detect restriction fragment length polymorphisms (RFLPs) associated with the ribosomal RNA genes for epidemiological typing (ribotyping) is a powerful and readily applicable tool. Different probes and enzymes for ribotyping were compared for a series of 73 unrelated Legionella pneumophila serogroup 1 strains. The probes compared were cDNAs, transcribed from $L$. pneumophila or Escherichia coli rRNA subunits, and a cloned $L$. pneumophila rRNA gene. The cloned rRNA gene probe gave the best discrimination and this probe was further compared with cloned probes comprised of randomly selected (non-rRNA) parts of the L. pneumophila chromosome. In this instance the greatest discrimination was achieved when one of the non-ribosomal RNA gene probes was employed. The overall discrimination of RFLP typing was enhanced by combining the data obtained with both rRNA and non-rRNA probes.
\end{abstract}

\section{Introduction}

Molecular methods for the epidemiological typing of bacterial strains are increasing in importance. One such technique is restriction endonuclease digest analysis in which differences between the sequences of the genomic DNAs of strains are detected following electrophoretic separation of the digests. When this method is applied to bacterial DNA a large number of restriction fragments is produced, and these cannot be completely separated on the gel. The resulting complex patterns of poorly resolved bands present considerable difficulties in interpretation. For this reason, probes that hybridise to a selected proportion of the bacterial genome have been used to produce simple strain-dependent patterns of bands which may be read and compared readily. Various approaches have been used to select suitable probes for this purpose. ${ }^{1}$ Cloned genomic fragments from genes of known function ${ }^{2,3}$ or randomly selected genomic fragments from the organism of interest ${ }^{4-6}$ may be employed. An alternative approach in which the need for cloning may be avoided, is to use bacterial $16 \mathrm{~S}$ and 23S rRNA subunits, suitably labelled, as probes (riboprobes). ${ }^{7-10}$ An advantage of this approach is that, because of the conserved nature of parts of the rRNA sequences, such probes hybridise with the DNA from all bacterial species making the system widely applicable. Escherichia coli rRNA is commercially available and, therefore, has often been used as

Received 5 Nov. 1990; revised version accepted 17 Dec. 1990. a riboprobe for the rRNA genes of other species ${ }^{7-9}$ but alternative heterologous ${ }^{7}$ and homologous riboprobes ${ }^{8,10}$ have also been employed. Other workers have used cloned rRNA genes from various species as probed for ribotyping. ${ }^{11-13}$

A further approach that avoids the need for cloning is the use of DNA sequences from bacteriophage M13 as probes. The genome of this phage includes a polynucleotide sequence which is found in multiple copies in prokaryotic and eukaryotic species. ${ }^{14} \mathrm{~A}$ drawback of the M13 system is that the hybridising sequences are short and radioactive labels are required for their efficient detection.

We have employed various probes, either rRNA based or randomly selected cloned genome fragments, and restriction endonucleases for restriction fragment length polymorphism (RFLP) typing of Legionella pneumophila serogroup 1 strains. The results obtained were compared and the discriminatory power of each typing system was assessed by calculation of the numerical indices of discrimination. ${ }^{15}$

\section{Materials and methods}

\section{Bacterial strains}

Isolates of $L$. pneumophila serogroup 1 were obtained during 1979-1989 from Europe, North America and Asia. Their identity was confirmed on the basis of nutritional, biochemical and serological characters. ${ }^{16}$ The strains were stored on glass beads at $-70^{\circ} \mathrm{C}$ and 
recovered on to buffered charcoal yeast extract medium (BCYE); cultures were incubated for $72 \mathrm{~h}$ at $37^{\circ} \mathrm{C}$ before growth was harvested in saline and pelleted by centrifugation.

For this study, 73 epidemiologically unrelated strains were examined. Strains isolated within the same year were considered to be related, and, therefore, excluded from the study, if they were taken from patients with a possible or confirmed common source of infection or, in the case of environmental isolates, if they were cultured from the same locality as any other environmental or clinical strain. Fiftynine of the 73 strains were randomly selected from the isolates used previously to evaluate an RFLP typing method $; 6$ the other 14 strains were selected as being of different RFLP types in tests with the probe $\lambda$ NS20/ 21. Nineteen of the 59 random isolates were used to compare riboprobes. These strains belonged to a subset of the ribotypes defined by the probe $\lambda 142$ (table). A further eight phenotypically distinct but apparently genetically homogenous strains, which were isolated from a common environmental source, ${ }^{17}$ were also examined.

\section{Southern blotting}

Southern blots of DNA from L. pneumophila strains after digestion with the restriction endonucleases $\mathrm{NciI}$ and $C l a I$ were prepared as described previously. ${ }^{6}$

\section{Preparation of probe DNA and hybridisation}

E. coli rRNA (BCL) and L. pneumophila rRNA ${ }^{11}$ were used as templates to generate biotin-labelled complementary DNA (cDNA) probes by means of reverse transcriptase. ${ }^{18} \lambda$-Phage DNAs $\lambda$ NS20, $\lambda$ NS2 1 $(\lambda N S 20 / 21),{ }^{6} \lambda 142^{11}$ and $\lambda \operatorname{leg} 1^{17}$ were prepared and labelled with biotin-11-dUTP by random primer extension. ${ }^{19}$ Biotinylated probes were hybridised to Southern blots and the bound biotin was detected with

Table. Summary of RFLP typing results of L. pneumophila serogroup 1

\begin{tabular}{|c|c|c|c|c|c|c|c|c|}
\hline \multirow[b]{2}{*}{ Strain no. } & \multirow[b]{2}{*}{ Source } & \multicolumn{7}{|c|}{ Results obtained with typing system (RFLP type) } \\
\hline & & $\underset{\lambda 142 / N c i I}{\mathrm{~A}}$ & $\begin{array}{c}\text { B } \\
\lambda 142 / C l a I\end{array}$ & $\begin{array}{c}\mathrm{C} \\
\text { L. pneumophila } \\
\text { cDNA/NciI }\end{array}$ & $\begin{array}{c}\text { D } \\
E . \text { coli } \\
\text { cDNA/NciI }\end{array}$ & $\begin{array}{c}\text { E } \\
\text { E. coli } \\
\text { cDNA/ClaI }\end{array}$ & $\begin{array}{c}\mathbf{F} \\
\lambda \mathrm{NS}_{20 / 21 /} \\
N c i \mathrm{I}\end{array}$ & $\underset{\lambda \mathrm{LEGl} / N c i \mathrm{I}}{\mathrm{G}}$ \\
\hline $\begin{array}{l}\text { NCTC } 11191 \\
\text { LC376 }\end{array}$ & $\begin{array}{l}\text { E (USA) } \\
C \text { (UK) }\end{array}$ & $\begin{array}{l}\text { A1 } \\
\text { A1 }\end{array}$ & $\begin{array}{l}\text { B1 } \\
\text { B1 }\end{array}$ & $\begin{array}{l}\text { NT } \\
\text { NT }\end{array}$ & $\begin{array}{l}\text { D4 } \\
\text { D4 }\end{array}$ & $\begin{array}{l}\text { E1 } \\
\text { NT }\end{array}$ & $\begin{array}{l}\mathrm{F} 2 \\
\mathrm{~F} 2\end{array}$ & $\begin{array}{l}\text { G1 } \\
\text { G1 }\end{array}$ \\
\hline $\begin{array}{l}\text { A310/80 } \\
\text { ML150 } \\
\text { LC436 }\end{array}$ & $\begin{array}{l}C(U K) \\
C(N) \\
C(Y u)\end{array}$ & $\begin{array}{l}\text { A2 } \\
\text { A2 } \\
\text { A2 }\end{array}$ & $\begin{array}{l}\text { B1 } \\
\text { B1 } \\
\text { B1 }\end{array}$ & $\begin{array}{l}\text { NT } \\
\text { NT } \\
\text { NT }\end{array}$ & $\begin{array}{l}\text { D5 } \\
\text { D5 } \\
\text { D5 }\end{array}$ & $\begin{array}{l}\text { NT } \\
\text { NT } \\
\text { NT }\end{array}$ & $\begin{array}{r}\text { F1 } \\
\text { F28 } \\
\text { F24 }\end{array}$ & $\begin{array}{l}\text { G3 } \\
\text { G3 } \\
\text { G3 }\end{array}$ \\
\hline LC474 & $\mathrm{E}(\mathrm{UK})$ & A3 & B3 & NT & D5 & NT & F7 & G18 \\
\hline LC421 & $\mathrm{C}(\mathrm{UK})$ & A4 & B6 & NT & D5 & NT & F25 & G12 \\
\hline $\begin{array}{l}\text { LC235 } \\
\text { ML47 } \\
\text { ML54 } \\
\text { ML68 } \\
\text { LC22 } \\
\text { LC36 }\end{array}$ & $\begin{array}{l}\mathrm{C}(\mathrm{Po}) \\
\mathrm{C}(\mathrm{UK}) \\
\mathrm{C}(\mathrm{UK}) \\
\mathrm{C}(\mathrm{UK}) \\
\mathrm{C}(\mathrm{Fr}) \\
\mathrm{C}(\mathrm{Fr})\end{array}$ & $\begin{array}{l}\text { A5 } \\
\text { A6 } \\
\text { A6 } \\
\text { A6 } \\
\text { A6 } \\
\text { A6 }\end{array}$ & $\begin{array}{l}\text { B9 } \\
\text { B2 } \\
\text { B5 } \\
\text { B2 } \\
\text { B2 } \\
\text { B9 }\end{array}$ & $\begin{array}{l}\text { C6 } \\
\text { C7 } \\
\text { C4 } \\
\text { C7 } \\
\text { C7 } \\
\text { C7 }\end{array}$ & $\begin{array}{l}\text { D5 } \\
\text { NT } \\
\text { NT } \\
\text { NT } \\
\text { NT } \\
\text { NT }\end{array}$ & $\begin{array}{l}\text { E2 } \\
\text { NT } \\
\text { NT } \\
\text { E2 } \\
\text { NT } \\
\text { E2 }\end{array}$ & $\begin{array}{r}\text { F8 } \\
\text { F20 } \\
\text { F26 } \\
\text { F28 } \\
\text { F17 } \\
\text { F21 }\end{array}$ & $\begin{array}{r}\text { G2 } \\
\text { G11 } \\
\text { G3 } \\
\text { G3 } \\
\text { G3 } \\
\text { G3 }\end{array}$ \\
\hline $\begin{array}{l}\text { A175/79 } \\
\text { ML87 } \\
\text { LC26 } \\
\text { LC32 } \\
\text { LC81 } \\
\text { LC359 } \\
\text { LC360 } \\
\text { LC400 } \\
\text { LC433 } \\
\text { LC470 } \\
\text { LC521 } \\
\text { LC620 } \\
\text { LC631 } \\
\text { LC636 } \\
\text { LC746 } \\
\text { LRU7 } \\
\text { LRU16 }\end{array}$ & $\begin{array}{l}C \text { (UK) } \\
E \text { (HK) } \\
C \text { (Fr) } \\
C \text { (Fr) } \\
C \text { (UK) } \\
\text { ?(USA) } \\
\text { ?(USA) } \\
\text { E (UK) } \\
C \text { (UK) } \\
E \text { (UK) } \\
\text { E (UK) } \\
C \text { (UK) } \\
E \text { (UK) } \\
\text { E (UK) } \\
E \text { (UK) } \\
E \text { (UK) } \\
E \text { (UK) }\end{array}$ & $\begin{array}{l}\text { A7 } \\
\text { A7 } \\
\text { A7 } \\
\text { A7 } \\
\text { A7 } \\
\text { A7 } \\
\text { A7 } \\
\text { A7 } \\
\text { A7 } \\
\text { A7 } \\
\text { A7 } \\
\text { A7 } \\
\text { A7 } \\
\text { A7 } \\
\text { A7 } \\
\text { A7 } \\
\text { A7 }\end{array}$ & $\begin{array}{l}\text { B1 } \\
\text { B3 } \\
\text { B1 } \\
\text { B1 } \\
\text { B1 } \\
\text { B1 } \\
\text { B1 } \\
\text { B3 } \\
\text { B1 } \\
\text { B1 } \\
\text { B1 } \\
\text { B1 } \\
\text { B1 } \\
\text { B1 } \\
\text { B1 } \\
\text { B1 } \\
\text { B1 }\end{array}$ & $\begin{array}{l}\text { NT } \\
\text { C6 } \\
\text { C6 } \\
\text { C6 } \\
\text { C6 } \\
\text { C6 } \\
\text { C6 } \\
\text { C6 } \\
\text { C6 } \\
\text { C6 } \\
\text { C6 } \\
\text { C6 } \\
\text { NT } \\
\text { C6 } \\
\text { C6 } \\
\text { C6 } \\
\text { NT }\end{array}$ & $\begin{array}{l}\text { NT } \\
\text { NT } \\
\text { NT } \\
\text { NT } \\
\text { NT } \\
\text { NT } \\
\text { NT } \\
\text { NT } \\
\text { NT } \\
\text { NT } \\
\text { NT } \\
\text { NT } \\
\text { NT } \\
\text { NT } \\
\text { NT } \\
\text { NT } \\
\text { NT }\end{array}$ & $\begin{array}{l}\text { NT } \\
\text { E3 } \\
\text { NT } \\
\text { NT } \\
\text { NT } \\
\text { NT } \\
\text { NT } \\
\text { NT } \\
\text { NT } \\
\text { NT } \\
\text { NT } \\
\text { NT } \\
\text { NT } \\
\text { NT } \\
\text { NT } \\
\text { NT } \\
\text { NT }\end{array}$ & $\begin{array}{r}\text { F27 } \\
\text { F31 } \\
\text { F1 } \\
\text { F1 } \\
\text { F1 } \\
\text { F1 } \\
\text { F6 } \\
\text { F1 } \\
\text { F1 } \\
\text { F1 } \\
\text { F1 } \\
\text { F1 } \\
\text { F1 } \\
\text { F1 } \\
\text { F1 } \\
\text { F1 } \\
\text { F1 }\end{array}$ & $\begin{array}{l}\text { G3 } \\
\text { G4 } \\
\text { G3 } \\
\text { G3 } \\
\text { G3 } \\
\text { G3 } \\
\text { G3 } \\
\text { G3 } \\
\text { G3 } \\
\text { G3 } \\
\text { G3 } \\
\text { G3 } \\
\text { G3 } \\
\text { G3 } \\
\text { G3 } \\
\text { G3 } \\
\text { G3 }\end{array}$ \\
\hline $\begin{array}{l}\text { NCTC } 11286 \\
\text { LC } 27 \\
\text { LC51 }\end{array}$ & $\begin{array}{l}C \text { (USA) } \\
C(\mathrm{Fr}) \\
C(\mathrm{Fr})\end{array}$ & $\begin{array}{l}\text { A8 } \\
\text { A8 } \\
\text { A8 }\end{array}$ & $\begin{array}{l}\text { B5 } \\
\text { B6 } \\
\text { B5 }\end{array}$ & $\begin{array}{l}\mathrm{C} 1 \\
\mathrm{C} 2 \\
\mathrm{C} 4\end{array}$ & $\begin{array}{l}\text { NT } \\
\text { NT } \\
\text { NT }\end{array}$ & $\begin{array}{l}\text { NT } \\
\text { NT } \\
\text { NT }\end{array}$ & $\begin{array}{r}\text { F3 } \\
\text { F22 } \\
\text { F13 }\end{array}$ & $\begin{array}{l}\text { G10 } \\
\text { G16 } \\
\text { G10 }\end{array}$ \\
\hline
\end{tabular}


Table-cont.

\begin{tabular}{|c|c|c|c|c|c|c|c|c|}
\hline \multirow[b]{2}{*}{ Strain no. } & \multirow[b]{2}{*}{ Source } & \multicolumn{7}{|c|}{ Results obtained with typing system (RFLP type) } \\
\hline & & $\underset{\lambda 142 / N c i I}{\mathrm{~A}}$ & $\underset{\lambda 142 / C l a \mathrm{I}}{\text { B }}$ & $\begin{array}{c}\mathrm{C} \\
\text { L. pneumophila } \\
\text { cDNA/NciI }\end{array}$ & $\begin{array}{c}\text { D } \\
\text { E. coli } \\
\text { cDNA/NciI }\end{array}$ & $\begin{array}{c}\text { E } \\
\text { E. coli } \\
\text { cDNA/ClaI }\end{array}$ & $\begin{array}{c}\mathrm{F} \\
\lambda \underset{N S 20 / 21 /}{N c i I}\end{array}$ & $\frac{\mathrm{G}}{\lambda \mathrm{LEG} 1 / N c i \mathrm{I}}$ \\
\hline $\begin{array}{l}\text { LC19 } \\
\text { LC62 } \\
\text { LC190 } \\
\text { LC199 } \\
\text { LC358 } \\
\text { LC518 }\end{array}$ & $\begin{array}{l}C \text { (Fr) } \\
C \text { (N) } \\
C \text { (Fr) } \\
C \text { (Fr) } \\
\text { E (Sing) } \\
\text { E (UK) }\end{array}$ & $\begin{array}{l}\text { A9 } \\
\text { A9 } \\
\text { A9 } \\
\text { A9 } \\
\text { A9 } \\
\text { A9 }\end{array}$ & $\begin{array}{l}\text { B5 } \\
\text { B6 } \\
\text { B6 } \\
\text { B6 } \\
\text { B5 } \\
\text { B2 }\end{array}$ & $\begin{array}{l}\text { NT } \\
\text { C1 } \\
\text { C1 } \\
\text { C1 } \\
\text { C1 } \\
\text { C4 }\end{array}$ & $\begin{array}{l}\text { NT } \\
\text { D1 } \\
\text { NT } \\
\text { NT } \\
\text { NT } \\
\text { NT }\end{array}$ & $\begin{array}{l}\text { NT } \\
\text { NT } \\
\text { NT } \\
\text { NT } \\
\text { NT } \\
\text { NT }\end{array}$ & $\begin{array}{r}\text { F13 } \\
\text { F26 } \\
\text { F26 } \\
\text { F26 } \\
\text { F4 } \\
\text { F39 }\end{array}$ & $\begin{array}{r}\text { G2 } \\
\text { G16 } \\
\text { G16 } \\
\text { G16 } \\
\text { G2 } \\
\text { G2 }\end{array}$ \\
\hline $\begin{array}{l}\text { LC20 } \\
\text { LC57 } \\
\text { LC99 } \\
\text { LC173 } \\
\text { LC185 }\end{array}$ & $\begin{array}{l}\text { E (Fr) } \\
C(F r) \\
C(F r) \\
C(F r) \\
C(F r)\end{array}$ & $\begin{array}{l}\text { A10 } \\
\text { A10 } \\
\text { A10 } \\
\text { A10 } \\
\text { A10 }\end{array}$ & $\begin{array}{r}\text { B10 } \\
\text { B6 } \\
\text { B6 } \\
\text { B6 } \\
\text { B6 }\end{array}$ & $\begin{array}{l}\text { C2 } \\
\text { C2 } \\
\text { C2 } \\
\text { NT } \\
\text { NT }\end{array}$ & $\begin{array}{l}\text { D1 } \\
\text { D1 } \\
\text { D1 } \\
\text { NT } \\
\text { NT }\end{array}$ & $\begin{array}{l}\text { NT } \\
\text { NT } \\
\text { NT } \\
\text { NT } \\
\text { NT }\end{array}$ & $\begin{array}{r}\text { F1 } \\
\text { F5 } \\
\text { F5 } \\
\text { F5 } \\
\text { F26 }\end{array}$ & $\begin{array}{l}\text { G16 } \\
\text { G16 } \\
\text { G16 } \\
\text { G16 } \\
\text { G16 }\end{array}$ \\
\hline $\begin{array}{l}\text { LC380 } \\
\text { LRU89 }\end{array}$ & $\begin{array}{l}\text { E (UK) } \\
C(U K)\end{array}$ & $\begin{array}{l}\text { A11 } \\
\text { A11 }\end{array}$ & $\begin{array}{r}\text { B3 } \\
\text { B11 }\end{array}$ & $\begin{array}{l}\text { C3 } \\
\text { C3 }\end{array}$ & $\begin{array}{l}\text { D2 } \\
\text { D2 }\end{array}$ & $\begin{array}{l}\text { NT } \\
\text { E3 }\end{array}$ & $\begin{array}{l}\text { F10 } \\
\text { F10 }\end{array}$ & $\begin{array}{r}\text { G17 } \\
\text { G6 }\end{array}$ \\
\hline $\begin{array}{l}\text { NCTC } 11192 \\
\text { ML72 } \\
\text { LC5 } \\
\text { LC80 } \\
\text { LC230 } \\
\text { LC372 } \\
\text { LC412 } \\
\text { LC423 } \\
\text { LC460 } \\
\text { LC480 } \\
\text { LC512 }\end{array}$ & $\begin{array}{l}C \text { (USA) } \\
C \text { (I) } \\
C \text { (UK) } \\
C \text { (Sp) } \\
C \text { (Eu) } \\
C \text { (UK) } \\
C \text { (Gr) } \\
C \text { (UK) } \\
C \text { (Fr) } \\
E \text { (UK) } \\
C \text { (UK) }\end{array}$ & $\begin{array}{l}\text { A12 } \\
\text { A12 } \\
\text { A12 } \\
\text { A12 } \\
\text { A12 } \\
\text { A12 } \\
\text { A12 } \\
\text { A12 } \\
\text { A12 } \\
\text { A12 } \\
\text { A12 }\end{array}$ & $\begin{array}{l}\text { B4 } \\
\text { B4 } \\
\text { B7 } \\
\text { B7 } \\
\text { B7 } \\
\text { B8 } \\
\text { B7 } \\
\text { B4 } \\
\text { B4 } \\
\text { B4 } \\
\text { B4 }\end{array}$ & $\begin{array}{l}\text { NT } \\
\text { C4 } \\
\text { C4 } \\
\text { C4 } \\
\text { C4 } \\
\text { C4 } \\
\text { C4 } \\
\text { C4 } \\
\text { C4 } \\
\text { C4 } \\
\text { C4 }\end{array}$ & $\begin{array}{l}\text { NT } \\
\text { D1 } \\
\text { D1 } \\
\text { D1 } \\
\text { D1 } \\
\text { D1 } \\
\text { D1 } \\
\text { D1 } \\
\text { D1 } \\
\text { D1 } \\
\text { D1 }\end{array}$ & $\begin{array}{l}\text { NT } \\
\text { NT } \\
\text { NT } \\
\text { NT } \\
\text { NT } \\
\text { NT } \\
\text { NT } \\
\text { NT } \\
\text { NT } \\
\text { NT } \\
\text { NT }\end{array}$ & $\begin{array}{r}\text { F5 } \\
\text { F23 } \\
\text { F14 } \\
\text { F14 } \\
\text { F14 } \\
\text { F19 } \\
\text { F14 } \\
\text { F5 } \\
\text { F26 } \\
\text { F5 } \\
\text { F5 }\end{array}$ & $\begin{array}{l}\text { G16 } \\
\text { G16 } \\
\text { G13 } \\
\text { G13 } \\
\text { G13 } \\
\text { G13 } \\
\text { G13 } \\
\text { G16 } \\
\text { G16 } \\
\text { G16 } \\
\text { G16 }\end{array}$ \\
\hline LC435 & $\mathrm{C}(\mathrm{Gr})$ & A13 & B6 & $\mathrm{C} 2$ & D1 & NT & F18 & G14 \\
\hline LC457 & E (Sing) & A14 & B1 & $\mathrm{C} 5$ & D3 & NT & F23 & G3 \\
\hline LC607 & E (UK) & A2 & B7 & NT & NT & NT & F32 & G3 \\
\hline A $32 / 81$ & E (UK) & A6 & B2 & NT & NT & E2 & $\mathrm{F} 11$ & G7 \\
\hline $\begin{array}{l}\text { NCTC } 12025 \\
\text { LC751A }\end{array}$ & $\begin{array}{l}\text { ?(USA) } \\
\text { E (UK) }\end{array}$ & $\begin{array}{l}\text { A7 } \\
\text { A7 }\end{array}$ & $\begin{array}{l}\text { B1 } \\
\text { B1 }\end{array}$ & $\begin{array}{l}\text { NT } \\
\text { NT }\end{array}$ & $\begin{array}{l}\text { NT } \\
\text { NT }\end{array}$ & $\begin{array}{l}\text { NT } \\
\text { NT }\end{array}$ & $\begin{array}{l}\text { F30 } \\
\text { F47 }\end{array}$ & $\begin{array}{l}\text { G3 } \\
\text { G3 }\end{array}$ \\
\hline $\begin{array}{l}\text { A } 176 / 79 \\
\text { A } 100 / 81 \\
\text { LC638 } \\
\text { LC } 854\end{array}$ & $\begin{array}{l}\text { C (USA) } \\
\text { E (Aus) } \\
\text { E (UK) } \\
\text { E (UK) }\end{array}$ & $\begin{array}{l}\text { A8 } \\
\text { A8 } \\
\text { A8 } \\
\text { A8 }\end{array}$ & $\begin{array}{l}\text { B5 } \\
\text { B5 } \\
\text { B5 } \\
\text { B4 }\end{array}$ & $\begin{array}{l}\text { NT } \\
\text { NT } \\
\text { NT } \\
\text { NT }\end{array}$ & $\begin{array}{l}\text { NT } \\
\text { NT } \\
\text { NT } \\
\text { NT }\end{array}$ & $\begin{array}{l}\text { NT } \\
\text { NT } \\
\text { NT } \\
\text { E4 }\end{array}$ & $\begin{array}{l}\text { F16 } \\
\text { F12 } \\
\text { F37 } \\
\text { F46 }\end{array}$ & $\begin{array}{r}\text { G5 } \\
\text { G10 } \\
\text { G10 } \\
\text { G5 }\end{array}$ \\
\hline LC787A & $\mathrm{E}(\mathrm{UK})$ & A9 & B5 & NT & NT & E5 & F44 & G2 \\
\hline LC564 & $\mathrm{E}$ (Ost) & A12 & B4 & NT & NT & NT & F29 & G15 \\
\hline A218/80 & $\mathrm{E}(\mathrm{UK})$ & A15 & B2 & NT & NT & E2 & F15 & G8 \\
\hline $\begin{array}{l}\text { LC635 } \\
\text { LC657 }\end{array}$ & $\begin{array}{l}C(Y u) \\
E(T k)\end{array}$ & $\begin{array}{l}\text { A16 } \\
\text { A16 }\end{array}$ & $\begin{array}{l}\text { B1 } \\
\text { B3 }\end{array}$ & $\begin{array}{l}\text { NT } \\
\text { NT }\end{array}$ & $\begin{array}{l}\text { NT } \\
\text { NT }\end{array}$ & $\begin{array}{l}\text { E1 } \\
\text { E3 }\end{array}$ & $\begin{array}{l}\text { F36 } \\
\text { F35 }\end{array}$ & $\begin{array}{l}\text { G3 } \\
\text { G3 }\end{array}$ \\
\hline LC792A & $\mathrm{E}(\mathrm{UK})$ & A17 & B5 & NT & NT & E5 & F45 & G9 \\
\hline
\end{tabular}

C, clinical; E, environmental; ?, unknown; Aus, Australia; Eu, Europe (more than one country visited during incubation period); Fr, France; Gr, Greece; HK, Hong Kong; I, Italy; N, Netherlands; Ost, Austria; Po, Poland; Sing, Singapore; Sp, Spain; Tk, Turkey; UK, United Kingdom; USA, United States of America; Yu, Yugoslavia.

NT, not typed.

a streptavidin-alkaline phosphatase conjugate (Gibco-BRL) as described previously. ${ }^{19}$

\section{Interpretation of the probed Southern blots and determination of discrimination indices}

The reproducibility of RFLP typing with the probes $\lambda$ NS20/21 has been thoroughly evaluated elsewhere. ${ }^{6}$ Banding patterns were analysed as described previously. ${ }^{6}$ Simpson's numerical index of discrimination was calculated as described by Hunter and Gaston. ${ }^{15}$

\section{Results}

\section{Comparison of riboprobes}

Three different riboprobes, labelled by incorporation of biotin-11-dUTP, were compared for the RFLP typing (ribotyping) of a series of $19 \mathrm{~L}$. pneumophila serogroup 1 strains (table; typing systems $A, C$ and D): (i) $\lambda 142$, a cloned $L$. pneumophila rRNA cistron $;^{11}$ (ii) cDNA transcripts of commercially prepared $E$. coli rRNA; and (iii) cDNA transcripts of $L$. pneumophila rRNA. 
The probes each hybridised with several NciI restriction fragments derived from the DNAs of the strains examined (fig. 1). The restriction fragment patterns of some strains differed according to the rRNA template used to prepare the cDNA transcripts. Faint bands, which were not detected by the $E$. coli transcripts, were often revealed by the $L$. pneumophila probe. There was also some indication that the relative staining intensity of the smallest restriction fragment observed was greater with the $L$. pneumophila probe. When $\lambda 142$, the cloned rRNA cistron, was employed as probe, the same strain-specific patterns were seen but the faint bands detected by the $L$. pneumophila cDNA probe were of increased intensity relative to the other bands and further bands were also present. The most prominent of these bands was $c .3 \mathrm{~kb}$, as judged by its position relative to the $\lambda$-phage markers, in analyses of 18 of the 19 strains (when all 73 strains included in the study were examined, the $3-\mathrm{kb}$ band was present in 71). Simpson's numerical index of discrimination (the probability, for a given typing system, that two unrelated strains will be of different types) was calculated for each of the three ribotyping probes and found to be 0.713 (seven patterns), 0.696 (six patterns) and $0 \cdot 380$ (four patterns) for $\lambda 142$ (system A), the L. pneumophila rRNA transcripts (system C) and the E. coli rRNA transcripts (system D), respectively.

When DNA from L. pneumophila strains was digested with the restriction endonuclease ClaI before RFLP typing with the $\lambda 142$ and $E$. coli cDNA probes, the results obtained were similar (table; typing systems B and E). Fig. 2 shows that, as for NciI, additional bands were revealed by the cloned probe.

\section{Direct comparison of restriction endonucleases}

ClaI and $N c i$ were compared by ribotyping a series of $73 \mathrm{~L}$. pneumophila serogroup 1 strains with the probe $\lambda 142$ (table; typing systems A and B). Digestion with ClaI, which has a hexanucleotide recognition sequence, produced $L$. pneumophila DNA restriction fragments with a higher mol.-wt distribution than the pentanucleotide site-specific endonuclease $\mathrm{NciI}$. Consistent with this, Southern blotting of ClaI digests with the probe $\lambda 142$ revealed restriction fragments which

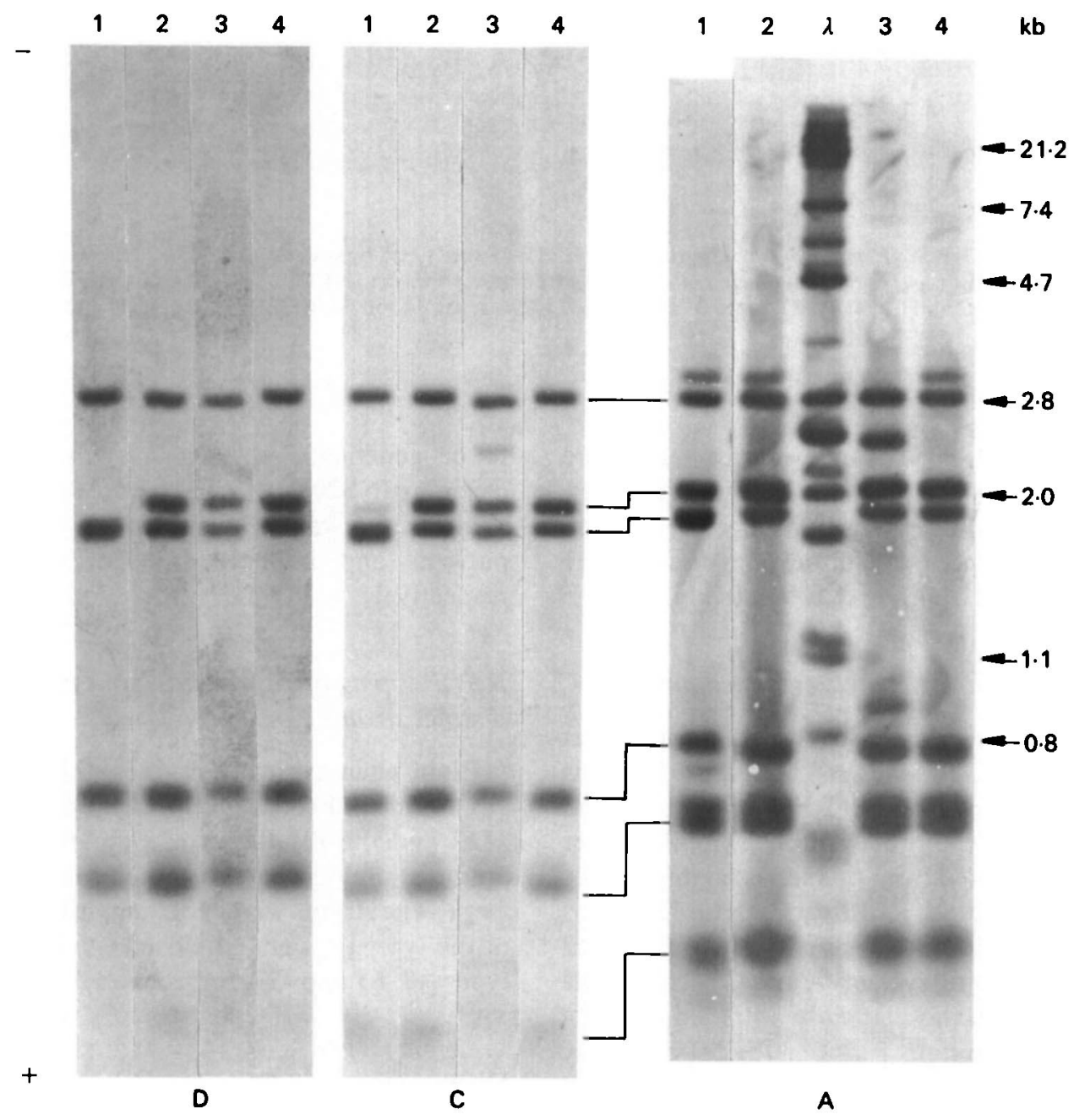

Fig. 1. Ribotyping with NciI. Four L. pneumophila serogroup 1 strains (1-4) were typed by systems A, C and D as indicated. The track marked $\lambda$ shows restriction fragments ( $2 \mathrm{ng}$ ) of bacteriophage $\lambda$ (PstI and EcoRI digests). The lines linking bands for typing systems A and C indicate species with identical relative mobilities. Strain 1: LRU89, types A11, C3 and D2; 2: LC412, types A12, C4 and D1; 3: LC435, types A13, C2 and D1; 4: LC372, types A12, C4 and D1. 


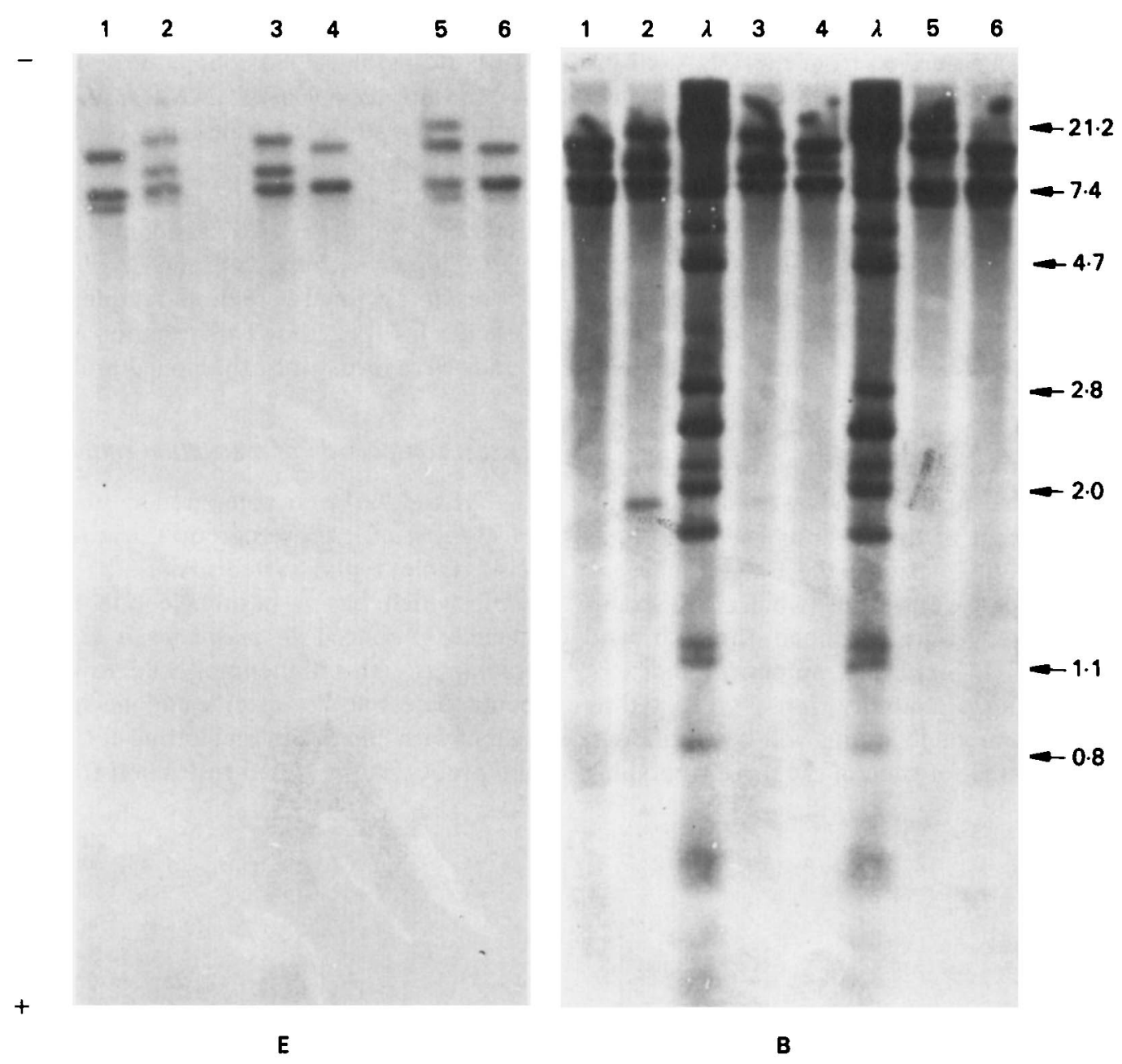

Fig. 2. Ribotyping with ClaI. Six L. pneumophila serogroup 1 strains (1-6) were typed by systems B and E as indicated. The track marked $\lambda$ shows restriction fragments (2ng) of bacteriophage $\lambda$ (PstI and EcoRI digests). Strain 1: NCTC 11191, types B1 and E1; 2: LC235, types B9 and E2; 3: ML68, types B2 and E2; 4: ML87, types B3 and E3; 5: LC854, types B4 and E4; 6: LRU89, types B11 and E3.

were of greater mol.-wt, fewer in number and more closely spaced than the equivalent $\mathrm{Nci}$ fragments (cf. figs. 1 and 2). Simpson's numerical indices of discrimination were 0.836 and 0.881 for the enzymes ClaI (11 patterns) and NciI (17 patterns), respectively.

\section{Comparison of $\lambda 142$ with random cloned probes}

A series of 59 unrelated strains was selected at random from the $L$. pneumophila serogroup 1 strains used previously to evaluate an RFLP typing method based on the use of the probes $\lambda$ NS20/21. ${ }^{6}$ A further 14 strains were selected from this series on the basis of their different $\lambda$ NS20/21 RFLP types. The 73 strains were subjected to RFLP analysis with the probes $\lambda 142$ and $\lambda$ leg 1 (table; typing systems $A$ and $G$ ). The results were compared with those already obtained with the probes $\lambda$ NS20/21 (system F). ${ }^{6}$ For the 59 randomly selected strains 25,13 and 14 different restriction fragment patterns and discrimination indices of 0.902 , 0.767 and 0.863 were observed for the probes $\lambda \mathrm{NS} 20 /$ $21, \lambda \operatorname{leg} 1$ and $\lambda 142$, respectively.

When the 14 additional strains, which were known to be genetically heterologous (as judged by their different $\lambda$ NS20/21 RFLP types), were included in the analysis the values were 39,18 and 18 different patterns and indices of $0.936,0.795$ and 0.881 respectively.

\section{RFLP typing of eight related but phenotypically distinct strains}

Eight phenotypically distinct strains from a single environmental source were analysed with the probe $\lambda 142$ and the results were compared with the data obtained previously ${ }^{12}$ with the probes $\lambda$ NS20/21 and $\lambda \operatorname{leg} 1$. The strains were indistinguishable, irrespective of the typing system employed (A, F or G), being of types $A 7, F 1$ and $G 3$, respectively.

\section{Discussion}

The comparison of ribotyping probes showed that the two cDNAs, which were transcribed from $L$. pneumophila or $E$. coli rRNAs, each identified similar 
bands with NciI-digested $L$. pneumophila DNAs. The pattern of bands differed by the presence of additional faint bands when the L. pneumophila probe was used, and in variations in intensity of the bands detected. These results are in agreement with those reported by Stull and colleagues who showed that indistinguishable band patterns were obtained for DNA from Pseudomonas cepacia or Haemophilus influenzae with both homologous and heterologous rRNA subunit probes. ${ }^{8}$ The additional faint bands, which form part of the homologous-probe patterns seen in this study, are probably present because of variations in the degree of homology between the L. pneumophila and E. coli rRNA genes at different loci. Such variations influence the melting temperature of the different probe-target duplexes formed and, therefore, the strength of the signal obtained. Signal differences are more marked for restriction fragments carrying a short segment of an rRNA gene together with a relatively long flanking sequence. Thus, restriction fragments carrying either short or variable fragments of the L. pneumophila rRNA genes hybridise with the $E$. coli cDNA rather inefficiently.

The cloned probe $\lambda 142$ comprises $>95 \%$ of the $16 \mathrm{~S}$ and $23 \mathrm{~S}$ rRNA genes, as determined by sequencing, together with $c .3 \mathrm{~kb}$ of L. pneumophila DNA flanking the rRNA cistron and $35 \mathrm{~kb}$ of $\lambda$ phage vector sequence. ${ }^{11}$ When $\lambda 142$ was employed as a riboprobe, the band patterns produced were similar to those obtained with the L. pneumophila cDNA probe. They differed chiefly in the presence of an additional band of c. $3 \mathrm{~kb}$ (in 71 of 73 strains). It is evident that this DNA fragment hybridised with part of the cloned DNA sequence flanking the $16 \mathrm{~S}$ and $23 \mathrm{~S}$ rRNA genes. Although three copies of the rRNA cistron are present in the genome of L. pneumophila (authors' unpublished observations), the intensity of the 3-kb band was lower than that of other bands of comparable size. Thus it seems probable that this non-rRNA sequence is present in association with only one of the three rRNA cistrons. The discriminatory powers of the rRNA probes used varied, that of $\lambda 142$ being the greatest. It should be noted that the strains typed with all three probes were selected from a small number of $\lambda 142$ RFLP types and the discrimination indices calculated were, therefore, low. Although the results are based on this small sample (19 strains), the conclusion that the discriminatory power of the cloned probe was greater than that of the remaining riboprobes is clearly well founded. It is based on the observation that the underlying patterns produced by the probes (seen with the $E$. coli cDNA probe) were identical, with an increasing number of additional bands observed with the L. pneumophila cDNA and $\lambda 142$ probes, respectively.

In addition to the advantage of being more discriminatory than the other riboprobes, $\lambda 142$ also had advantages in the ease with which it could be isolated and labelled. Furthermore, hybridisation of the vector sequences of $\lambda 142$ with mol.-wt markers derived from bacteriophage $\lambda$ allowed the positions of bands to be determined with great accuracy so that results on different gels could be compared readily.

The influence of the restriction endonucleases, ClaI and $N c i$, upon RFLP typing results was determined with the probe $\lambda 142$ and a series of 73 L. pneumophila serogroup 1 strains. ClaI was selected because a study in which a series of $L$. pneumophila strains were ribotyped with a probe composed of end-labelled $E$. coli rRNA fragments and a panel of hexanucleotide site restriction endonucleases had shown that this enzyme gave the best discrimination. ${ }^{20} \mathrm{NciI}$ was chosen from a panel of enzymes with tetra- penta- and hexanucleotide restriction sites (authors' unpublished results) because it produced a combination of clear patterns of bands in the convenient size range with good discrimination. The results obtained with the two enzymes show that $N c i$ gave greater discrimination between strains than ClaI. This difference was apparently due to the greater number and superior resolution of bands when the $L$. pneumophila rRNA genes are cleaved with $N c i$. An additional advantage of $\mathrm{NciI}$ over $\mathrm{ClaI}$ was that the differences between patterns were more distinct and, therefore, easier to interpret.

From the results of the ribotyping experiments, the optimum restriction endonuclease $(\mathrm{NciI})$ and probe ( $\lambda 142)$ were selected for use in the comparison of the RFLP typing results for a panel of 59 unrelated $L$. pneumophila serogroup 1 strains. The non-rRNA probes selected for comparison were $\lambda$ NS20/21 (comprising two clones carrying $L$. pneumophila Knoxville1 strain DNA fragments, of $c .8$ and $9 \mathrm{~kb}$ respectively) and $\lambda \operatorname{leg} 1$ (a clone carrying an $L$. pneumophila Philadelphia-1 strain DNA fragment of $c .6 \mathrm{~kb}$ ). These two probes had been selected from $L$. pneumophila gene libraries, in previous studies, by screening panels of clones empirically for those that gave the best results in RFLP typing. ${ }^{6,17}$ The numbers of bands observed and, therefore, the complexity of the patterns, were similar when the probes $\lambda 142$ and $\lambda$ NS20/ 21 were employed; the $\lambda$ leg 1 patterns were generally simpler. This is an important parameter because, although it would be possible to combine many cloned probes (as is done to a limited extent by the mixing of $\lambda N S 20$ and $\lambda$ NS21 to produce the probe $\lambda$ NS20/21) to gain discriminatory ability, this would result in complex patterns of bands which would be difficult to interpret. A further drawback of this approach would be a reduction in the signal-to-noise ratio on the blots. The greater discriminatory power of $\lambda$ NS20/21 indicated that this probe was derived from regions of the L. pneumophila genome that had more genetic diversity than that of the rRNA genes.

The analysis of 14 additional strains which were of different RFLP types when examined with the probe $\lambda N S 20 / 21$ gave a further indication of diversity of pattern types for the probes $\lambda 142$ and $\lambda$ legl. Inclusion of these strains increased the respective indices of discrimination of all three probes. This result was 
anticipated because these strains were selected on the basis of known genetic differences. Only three 'new' patterns were seen among the 14 strains examined with the probe $\lambda 142$. These data suggest that the theoretical total number of $\lambda 142$ pattern types for all L. pneumophila strains is relatively restricted compared with the respective totals for the other two probes. A possible explanation of this is that RFLPs detected by $\lambda 142$ are due mainly to re-arrangements between the three rRNA cistrons.

There was an unexpectedly low degree of correspondence between the results obtained with the three probes. For example, the six strains of RFLP type F26 with the probe $\lambda \mathrm{NS} 20 / 21$ were of four distinct $\lambda 142$ types (A types 6, 9, 10 and 12) and, conversely, the five strains of RFLP type A6 were of five distinct types when tested by system $F$. Combining the results obtained with these two probes increased the discrimination achieved considerably. When the results of typing the 59 randomly selected unrelated strains with $\lambda 142$ and $\lambda$ NS20/21 were combined, there were 34 types and the numerical index of discrimination was 0.935 . Little was gained by including the additional data obtained with the third probe, $\lambda \operatorname{leg} 1$, which increased the number of types to 35 and the index of discrimination to 0.936 .

Fourteen of the epidemiologically unrelated strains investigated were indistinguishable when typed by systems A, F and G. These strains (type A7, F1, G3) may represent a particularly widespread or, alternatively, an easily isolated $L$. pneumophila clone. The eight phenotypically distinct strains isolated from a single environmental source (a cooling tower) ${ }^{17}$ were also of this clonal type. This further evidence of the genetic homogeneity of these strains supports the suggestion ${ }^{17}$ that phenotypic diversification may occur in a relatively short period without apparent corresponding changes in the genotype. These results are further evidence that the reproducibility of RFLP typing is independent of both the phenotype of the strains and of the probe employed.

RFLP typing is a powerful epidemiological tool which gives highly reproducible and stable results. ${ }^{6,21}$ A considerable advantage of the method is that results accumulated over an extended period may be compared readily. The evidence reported here illustrates the importance of the choice of probe to the overall discriminatory ability of the technique and to the ease of interpretation of the results. It is clearly advantageous to compare the results obtained with a number of different probes and restriction endonucleases so that the system with the best combination of properties may be selected. From this study, the combination of $N c i$ digestion and the probe $\lambda \mathrm{NS} 20 / 21$, already in routine use in this laboratory, would appear to be the best single system for $L$. pneumophila RFLP typing.

\section{References}

1. Owen RJ. Chromosomal DNA fingerprinting - a new method of species and strain identification applicable to microbial pathogens. J Med Microbiol 1989; 30: 89-99.

2. Timms P, Eaves FW, Girjes AA, Lavin MF. Comparison of Chlamydia psittaci isolates by restriction endonuclease and DNA probe analyses. Infect Immun 1988; 56: 287-290.

3. Ogle JW, Janda JM, Woods DE, Vasil ML. Characterization and use of a DNA probe as an epidemiological marker for Pseudomonas aeruginosa. J Infect Dis 1987; 155: 119-126.

4. Meloni BP, Lymbery AJ, Thompson RCA. Characterization of Giardia isolates using a non-radiolabeled DNA probe, and correlation with the results of isoenzyme analysis. $\mathrm{Am} \mathrm{J}$ Trop Med Hyg 1989; 40: 629-637.

5. Saunders NA, Ridley AM, McLauchlin J, Taylor AG. Typing of Listeria monocytogenes for epidemiological studies using DNA probes. Acta Microbiol Hung 1989; 36: 205-209.

6. Saunders NA, Harrison TG, Haththotuwa A, Kachwalla N, Taylor AG. A method for typing strains of Legionella pneumophila serogroup 1 by analysis of restriction fragment length polymorphisms. J Med Microbiol 1990; 31 : 45-55.

7. Grimont F, Grimont PAD. Ribosomal ribonucleic acid gene restriction patterns as potential taxonomic tools. Ann Inst Pasteur Microbiol 1986; 137B : 165-175.

8. Stull TL, LiPuma JJ, Edlind TD. A broad-spectrum probe for molecular epidemiology of bacteria: ribosomal RNA. $J$ Infect Dis 1988; 157: 280-286.

9. Irino K, Grimont F, Casin I, Grimont PAD, The Brazilian Purpuric Fever Study Group. rRNA gene restriction patterns of Haemophilus influenzae biogroup aegyptius strains associated with Brazilian purpuric fever. $J$ Clin Microbiol 1988; 26: 1535-1538.

10. Owen RJ, Beck A, Dayal PA, Dawson C. Detection of genomic variation in Providencia stuartii clinical isolates by analysis of DNA restriction fragment length polymorphisms containing rRNA cistrons. J Clin Microbiol 1988; 26: 21612166.

11. Saunders NA, Harrison TG, Kachwalla N, Taylor AG.

Identification of species of the genus Legionella using a cloned rRNA gene from Legionella pneumophila. J Gen Microbiol 1988; 134: 2363-2374.

12. Andersen JK, Saunders NA. Epidemiological typing of Yersinia enterocolitica by analysis of restriction fragment length polymorphisms using a cloned ribosomal RNA gene. $J$ Med Microbiol 1990; 32: 179-187.

13. Yogev D, Halachmi D, Kenny GE, Razin S. Distinction of species and strains of mycoplasmas (Mollicutes) by genomic DNA fingerprints with an rRNA gene probe. $J$ Clin Microbiol 1988; 26: 1198-1201.

14. Huey B, Hall J. Hypervariable DNA fingerprinting in Escherichia coli: minisatellite probe from bacteriophage M13.J Bacteriol 1989; 171 : 2528-2532.

15. Hunter PR, Gaston MA. Numerical index of the discriminatory ability of typing systems: an application of Simpson's index of diversity. J Clin Microbiol 1988; 26: 2465-2466.

16. Harrison TG, Taylor AG (eds). A laboratory manual for Legionella. Chichester, John Wiley and Sons. 1988.

17. Harrison TG, Saunders NA, Haththotuwa A, Hallas G, Birtles RJ, Taylor AG. Phenotypic variation amongst genotypically homogeneous Legionella pneumophila serogroup 1 isolates: implications for the investigation of outbreaks of Legionnaires' disease. Epidemiol Infect 1990; 104: 171-180.

18. Saunders NA, Harrison TG. The application of nucleic acid probes and monoclonal antibodies to the investigation of Legionella infections. In : Harrison TG, Taylor AG (eds) A laboratory manual for Legionella. Chichester, John Wiley and Sons. 1988: 137-153.

19. Saunders NA. Analysis of restriction fragment length polymorphisms (RFLPs) for epidemiological tracing of bacteria using non-radioactive probes. Focus $1989 ; 11$ : 47-49.

20. Mao S, Barbaree JM, Wang Y et al. Ribotyping of Legionella pneumophila serogroup 1. Abstracts of the 89th Meeting of the American Society for Microbiology 1989; 183.

21. Saunders NA. Analysis of restriction fragment length polymorphisms (RFLPs) in the study of bacteria. In: Grange JM, Morgan NL, Skinner FA (eds) The Society for Applied Microbiology Technical Series 28. Oxford, Blackwell Scientific Publications. 1990: 227-244. 